\begin{tabular}{c} 
Volume and Issues Obtainable at Center for Sustainability Research and Consultancy \\
Journal of Business and Social Review in Emerging Economies \\
ISSN: 2519-089X (E): 2519-0326 \\
Volume 3: Issue 1 June 2017 \\
CSRᄃ \\
Journal homepage: www.publishing.globalcsrc.org/jbsee \\
\hline
\end{tabular}

\title{
Moderating Role of Access to Finance on Entrepreneurial Orientation, Market Orientation, Learning Orientation and SMEs Performance of Gem and Jewelry Industry in Thailand: A Proposed Model
}

\author{
${ }^{1}$ Mohd Noor MohdShariff, ${ }^{2}$ Nifaosan Raden Ahmad, ${ }^{3}$ Muhammad Haroon Hafeez \\ ${ }^{1}$ Lecturer, School of Business Management, College of Business, Universiti Utara Malaysia, 06010 UUM Sintok, \\ Kedah DarulAman, Malaysia, mdnoor@uum.edu.my \\ ${ }^{2} \mathrm{PhD}$ Scholar, School of Business Management, College of Business, Universiti Utara Malaysia, 06010 UUM \\ Sintok, Kedah DarulAman, Malaysia, fauzanmba@yahoo.com, \\ ${ }^{3}$ Lecturer, Institute of Management Sciences (Business Administration), Bahauddin Zakariya University, Multan, \\ Pakistan, haroonhafeez@bzu.edu.pk
}

\begin{tabular}{|c|c|}
\hline ARTICLEDETAILS & ABSTRACT \\
\hline History & Purpose: This study aims to propose a model that depicts the moderating \\
\hline Revised format: May 2017 & effect of access to finance on the relationship between entrepreneurial \\
\hline AvailableOnline: June 2017 & $\begin{array}{l}\text { orientation, market orientation, learning orientation and SMEs } \\
\text { performance. }\end{array}$ \\
\hline Keywords & Design/Methodology/Approach: This study adopts a survey research \\
\hline Entrepreneurial Orientation, & design by collecting primary data from the respondents due to the study \\
\hline Market Orientation, Learning & involves collecting data directly from SME owner-managers in order to \\
\hline Orientation, Access to & determine the moderating role of access to finance on the relationship \\
\hline Finance, SMEs Performance & $\begin{array}{l}\text { between entrepreneurial orientation, market orientation, learning } \\
\text { orientation and SMEs Performance. }\end{array}$ \\
\hline JEL Classificat & Findings: This study will provide a clear understanding of the impact of \\
\hline L11, L19, D83 & entrepreneurial orientation, market orientation, learning orientation on \\
\hline & $\begin{array}{l}\text { firm performance in the area of strategic management and } \\
\text { entrepreneurship. }\end{array}$ \\
\hline & $\begin{array}{l}\text { Implications/Originality/Value: The findings will be beneficial to } \\
\text { owner-managers of SMEs to understand the key factors that should be } \\
\text { encouraged and avoided in improving business performance. }\end{array}$ \\
\hline
\end{tabular}

(C) 2017 The authors, under a Creative Commons Attribution-

NonCommercial 4.0

Corresponding author's email address: mdnoor@uum.edu.my

Recommended citation: Shariff, M. N. M., Ahmad, N. R. \&Hafeez, M. H., (2017).Moderating Role of Access to Finance on Entrepreneurial Orientation, Market Orientation, Learning Orientation and SMEs Performance of Gem and Jewelry Industry in Thailand: A Proposed Model.Journal of Business and Social Review in Emerging

Economies, 3(1),109-120.DOI:https://doi.org/10.26710/jbsee.v3i1.184

\section{Introduction}

Presently, the governments all around the world pay attention to facilitating Small and Medium Enterprises (SMEs) since they play an important role in business world. Not only developing countries but developed countries that SMEs have been promoted in order to driving economic growth and generating employment opportunities. For instance, in the European Union, around $99 \%$ of all registered companies is SMEs sector contributes to the GDP between 2005 to 2010 compared with micro enterprises sector (Silivestru, 2012). In addition, in Ghana, the sector reduces unemployment rate together with contributing the growth of national GDP (Asare, 2014). Likewise, in Pakistan, the sector is $90 \%$ of all business enterprises that generate more 
than $30 \%$ of national GDP by providing job offers around 80\% (Ali et al., 2014). According to these significant roles of SMEs sector on the national economies, this sector has been raised the attention by scholars to comprehend particularly the performance of SMEs since it has been a major concern in strengthening the economies.

There are a number of challenges affecting the performance of SMEs especially in developing countries. Oreoluwa (2011) identifies financial support as one of the main factors responsible for SMEs's failure in Nigeria that hinders their ability to produce efficiently. Most of them are facing the perennial problem of inadequate finance, such as access to finance at relatively cheap cost. Ngek (2014) reveals the creation rate of successful SMEs in South Africa is one of the lowest rates in the world while most new SMEs in the country do not move beyond the first stage of growth to other stages. Similarly, despite the SMEs in Kenya generate the most employment opportunities but the creation rate of new SMEs has stagnated for a long time since they cannot move to the stage of maturity and collapse within first five years (Katua, 2014). Likewise, the failure rate of SMEs in Malaysia is $60 \%$ while many existing SMEs encounter problems to survive as competitive enterprises in the markets (Khaliqueet al., 2011).

On the one hand, strategic orientations seemed able to improve the success of SMEs. It can be explained further that strategic orientations are more likely to establish the firm's competitive advantage that leads to better performance. According to Herath and Mahmood (2013), understanding the influence of entrepreneurial orientation (EO), market orientation (MO), and learning orientation (LO) on performance of SMEs particularly in developing countries is very important since it might enhance the better performance. Moreover, there has been a lack of study to investigate the influence of these three strategic orientations on performance of SMEs at the same time, although there have been a lot of strategic orientations studied in existing literature (Herath\& Mahmood, 2014). In addition, access to finance is the life-blood for business firms to prosper by helping them to exploit growth and investment opportunities (Ahmad \&Arif, 2015; Musamali\&Tarus, 2013). Therefore, EO, MO, LO, and access to finance can be viewed as the vital resources of SMEs to improve their performance.

Despite the significant role of SMEs sector in the developing economies, the below expected performance is one of the most critical issues experiencing SMEs. In numerous studies have shown that strategic orientations can affect the SMEs performance. For instance, Herath and Mahmood (2014) found the positive linkages between EO, MO, LO and SMEs performance. Some studies found a significant relationship between EO and firm performance (Dada \& Watson, 2013; Ferreira et al., 2011). In contrast, Chandrakumaraet al. (2011) found no significant relationship between between EO and performance. Many studies revealed a significant effect of MO on firm performance (Qu \& Zhang, 2015; Ramayahet al., 2011). On the contrary, a study shows MO has a negative effect on firm performance (Apaydin, 2011). Likewise, some studies reveal LO has a significant relationship with performance (Martinetteet al., 2014; Frank et al., 2012). Conversely, some studies report insignificant relationship between LO and firm performance (Nybakk, 2012; Ma et al., 2011). However, the obtained results are contradictory and so little attention has been given to the influence of EO, MO, LO on performance in a single study model (Long, 2013).

Baron and Kenny (1986) imply the moderating variables are concerned over the inconclusive relationship between independent variable and dependent variable and that there maybe have some moderating variables have not been yet investigated. According to the research-based view (RBV) logic, access to finance is the basic machinery of firms that leads to firm growth (Adomakoet al., 2016). Some studies investigate the moderating role of access to finance on firm performance (Cowling \& Liu, 2013; Adomako\&Danso, 2014), meanwhile, a study investigates the mediating role (Aminu\&Shariff, 2014). Nevertheless, the moderating role of access to finance on combining the three strategic orientations; EO, MO, LO and SMEs performance so far remains unexplained by the existing literature. Based on the aforementioned gaps, this paper therefore aims to develop a conceptual framework for an investigation of the moderating role of access to finance on the relationship between EO, MO, LO and SMEs 
performance.

\section{Literature Review}

\subsection{Entrepreneurial Orientation (EO)}

It is generally acknowledged over the years that EO is a major construct in the literature of strategic management and entrepreneurship concerning the importance of EO to the survival of firms (Campos et al., 2012; Li et al., 2009). The most widely used meaning of EO is drawn on the work of Miller (1983) that enhanced further by Covin and Slevin (1989) and advanced later by Lumpkin and Dess (1996). According to the concept of Miller (1983), the three components of EO, including innovativeness, risktaking, and proactiveness have been generally used in the literature (Tope \&Rosli, 2014). Consequently, EO can be referred to a firm's willingness to act innovatively, proactively, and risky way to create and exploit environmental opportunities (Razak, 2011). The additional two components of EO, including competitive aggressiveness and autonomy have been added by Lumpkin and Dess (1996). In fact, there have been some debates among scholars on the dimensionality of EO. Some of them argue that EO is best viewed as a unidimensional construct (Rauch et al., 2009). For instance, Covin and Slevin (1989) imply that EO is best viewed as a unidimenstional construct, whereas Lumpkin and Dess (1996) suggest that viewing EO as a multidimensional construct is useful subject to the dimensions of EO may vary independently in a given context.

There have been a lot of studies investigate the role of EO on firm performance. Many studies adopted EO-unidimensional concept of Miller (1983) in predicting firm performance (Wong, 2012). Eggers et al. (2013) studied 660 SMEs in Australia found that EO is positively related to SME growth. Likewise, Dada and Watson (2013) studied 95 franchisors in the UK found that EO affects firm performance positively. In another study of 130 Chinese SMEs conducted by Zhang and Zhang (2012), reveals that there is a significant positive relationship between EO and business performance. Anderson and Eshima (2013), in a study on firm growth among 207 Japanese SMEs, report that EO is significant and positively related to firm growth. Similarly, Kantur (2016) investigated the influence of EO on business performance among 118 companies reveals that there is a positive relationship between EO and both financial and nonfinancial performances. In contrast, a study on the effect of EO on firm performance among 204 companies in Sri Lanka reports that there is no significant relationship between EO and firm performance. Likewise, Affendyet al. (2015) conducted a survey among SMEs in Malaysia found that EO does not significantly influence the performance of SMEs. It can be seen from the overall discussion that many studies report a positive relationship between EO and firm performance and some report otherwise. Consequently, the relationship between EO and SMEs performance seems to be inconclusive and requires further investigation. Therefore, the following proposition is developed.

- Proposition 1: EO is related to SMEs performance.

\subsection{Market Orientation (MO)}

According to Gheysariet al. (2012), MO was introduced in the academic literature in 1990s by extending from the marketing concept. At first, Narver and Slater (1990) proposed MO as the organizational culture to understanding the needs of customers, including customer orientation, competitor orientation, and inter-functional coordination. By contrast, Jaworski and Kohli (1993) postulated the later MO as the behavioral concept that relates to the three dimensional constructs of a frim's activities including, market intelligence generation, market intelligence dissemination, and organizational responsiveness. Consequently, both concepts of MO are proposed by Narver and Slater so-called MKTOR, and Jaworski and Kohli so-called MARKOR, the most widely accepted among scholars (Niculescuet al., 2013). Even though the notion of MO can be classified into two different theoretical approaches; cultural and behavioral approaches, both are the same in MO's philosophy that the customer is the key element (Gaur et al., 2011). In addition, Ma'atoofieet al. (2012) claim MO not merely pays attention to customers but also rivals and factors that affect the customer needs. It can be explained further that MO involves the use 
of a firm's skills to satisfy customers and respond environmental changes that leads to superior performance (Mahmoud \&Yusif, 2012). Kohli and Jaworski (1990) claim further that a firm's MO can lead to better performance. However, scholars have been questioned in the universal application of MO (Mahmoud, 2011).

Qu and Zhang (2015), conducted a study in the UK among 252 subsidiaries found the positive effect of MO on business performance. Also, a study conducted in Korea by using data from 156 franchisor companies reveals a significant positive effect of MO on business performance (Lee et al., 2015). Likewise, Ramayahet al. (2011) investigated 101 service organizations in the Northern region of Malaysia found that MO has a significant impact on organizational performance. In the same token, Charles et al., (2012) indicate a positive relationship between MO and performance with 147 manufacturing companies in Kenya. Another study in Ghana, Mahmoud (2011) reports a significant positive relationship between MO and performance of 191 SMEs. On one hand, a study of 316 SMEs in Canada indicates there is no direct influence of MO on firm performance (Roach, 2011). In the same vein, a study of 242 Malaysian public listed companies shows MO has no significant influence on firm performance (Arshad et al., 2012). Similarly, Suliyanto and Rahab (2012) examined the impact of MO in improving firm performance of $150 \mathrm{SMEs}$ in Indonesia found no direct influence of MO on the performance. In contrast, Apaydin (2011) found the negative relationship among MO and firm performance. Based on the overall discussion, the results on MO-performance linkage have been argued. Some found positive relationship while others found negative and no relationships. Therefore further investigation on the relationship among MO and SMEs performance is needed that the following proposition is formulated.

- Proposition 2: MO is related to SMEs performance.

\subsection{Learning Orientation (LO)}

The LO has become known as the acceptance of learning process in order to create and utilize knowledge throughout organization due to the importance of organizational learning has been recognized since 1960s (Tan \&Smyrnios, 2014; Ma'atoofi\&Tajeddini, 2010). So far, LO has become one of the most studied factors in the literature as it can influence a firm (Cheng et al., 2008). Consequently, the notion of LO has been brought to the attention of scholars as a source of competitive advantage that leads to better performance (Awasthy\& Gupta, 2011). According to Long (2013), LO refers to the knowledge creation and use in organizations to enhance competitive advantage that rivals find it difficult to imitate since it exists internally. In other words, LO concerns about a process of business firm that knowledge is conveyed and distributed within organization (Tajeddini, 2009). Moreover, Sinkula et al. (1997) imply that LO includes three dimensional constructs are commitment to learning, open-mindedness, and shared vision. Notwithstanding LO is one of the most valuable resources that help a firm to achieve superior performance, the linkage between LO and performance has been argued.

There have been a lot of studies investigate the influence of LO on business performance. In a study of pure 129 service and service-reliant organizations reports that there is a significant positive relationship between LO and business performance (Martinette\&Obenchain-Leeson (2012). Likewise, a study on public accounting service firms reveals a significant positive relationship between LO and firm performance (Martinetteet al., 2014). Frank et al. (2012) conducted a study on the relationship between LO and firm performance by collecting data from 228 Australian SMEs indicates that LO has a significant influence on performance. In addition, LO was found to be positively related to SMEs performance (Mahmood \& Hanafi, 2013). In contrast, Ma et al. (2011) found that there is no significant influence of LO on firm performance. Similarly, a study on 105 SMEs was conducted by Wolff et al. (2015), a result reveals no relationship was found between LO and firm growth. Another study conducted by Suliyanto and Rahab (2012) on the influence of LO on SMEs performance reports that there is no positive effect of LO to firm performance. In line with overall discussion, the relationship between LO and performance is unclear. Some studies report LO has a significant impact on performance while others indicate LO has a non-significant influence on performance. Consequently, the relationship between LO and performance 
requires further study. Therefore, the following proposition is formulated.

- Proposition 3: LO is related to SMEs performance

\subsection{Access to Finance (ATF) as Moderator}

Generally, it has been recognized that a firm's better access to finance can lead to superior performance. Kira and He (2012) acclaim that the significant factor such financial access can improve SME's productivity by reducing the unit cost of production resulting to generate an increase in profit. Similarly, Richard and Mori (2012) claim that easy access to finance is one of the key elements in determining growth and survival of SMEs since allows them undertake productive investments to compete with larger firms. Indeed, financial constraint is one of the most difficulties that SMEs have encountered, particularly small firms, to obtain their success (Belanova, 2013; Evans et al, 2015). Zarooket al. (2013) refer access to finance as the close proximity of such SMEs to sources of funding; bank loans, equity capital, and family finance, that can be classified into internal and external sources (Rossi, 2014). Arora (2014) describes further that access to finance can be explained as the possibility of individuals or enterprises to obtain financial products and services with non-price barriers. In addition, the term can be referred to the possibility that firms can access all kind of financial services with reasonable costs over an appropriate schedule (Bae et al., 2012; Chauhan, 2014; Gunto\& Alias, 2014).

The number of literature has reported that access to finance fosters the growth of SMEs. Moreira (2016) conducted a study to identify the impact on growth of SMEs among 1,327 internet and high-technologic businesses in Europe found that access to finance exerts a significant influence on growth of SMEs. Also another study investigated factors affecting the performance of small and micro enterprises by collecting data from 161 firms in Kenya found that access to financial resources significantly influences the performance of firms (Kamungeet al., 2014). Similarly, Adomakoet al. (2016) surveyed on the relationship between access to finance and firm growth by using data from 201 SMEs in Ghana found that the relationship is significantly positive. In fact, the literatures imply that a high level of access to finance can facilitates firms to access essential resources, in turn, firms are more likely to achieve growth performance. Liu et al. (2014) indicate that the access to finance significantly moderates the inter-relation between growth orientation and growth of small businesses in UK. In addition, Adomako and Danso (2014) reveal that the access to financial capital positively moderates the relationship between financial literacy and firm performance of 198 entrepreneurial firms operating in Ghana. Overall, the availability of financial capital can facilitate firms to improve their performance. However, there are limited studies have been investigated the moderating role of access to financial capital on the inter-relation between strategic orientation and firm performance. It is presumed that the access to finance is a potential moderator of strategic orientation-performance relationship, thus the following propositions are formulated.

\section{Proposition 4:}

- Access to finance moderates the relationship between EO and SMEs performance.

- Access to finance moderates the relationship between MO and SMEs performance.

- Access to finance moderates the relationship between LO and SMEs performance.

\subsection{Resource-based Theory}

The resource-based theory (RBT) is a fundamental theory of research in strategic management by employing to explain a firm's success. The concept of RBT was developed since 1980s from the resourcebased view (RBV) of a firm due to scholars dissatisfied the Porter's five forces model which explains that the competitive advantage of a firm lies in five external environments including; supplier power, buyer power, competitive rivalry, threat of substitution, and threat of new entry (Saqib\& Rashid, 2013). Subsequently, they have turned their attention to focus on the internal resources of a firm as sources of competitive advantage based on the assumption that a firm's internal resources influence firm growth (Lucas \&Kirillova, 2011). So far, the RBV has reached the maturity stage of theory that scholars use the 
term "resource-based theory" (RBT) instead of the term "resource-based view" (RBV) increasingly (Barney et al. 2011). The theory has been accepted widely as a theoretical framework in strategic management area to identify the internal resources of a firm in order to gain the competitive advantage (Brahma \& Chakraborty, 2011). The competitive advantage can be classified into two types depends on resources; temporary competitive advantage and sustained competitive advantage that the sustainable competitive advantage involves maintaining a sustainable advantage of a firm over rivals in a particular industry setting over time (O'Shannassy, 2008). Since the key element of RBT is focused on the role of internal resources of a firm that lead to sustained competitive advantage (Hart \& Dowell, 2011), Barney (1991) implies that a firm should identify its strategic capabilities are; valuable, rare, imperfectly imitable, and non-substitutable (VRIN) to achieve a sustained competitive advantage. Crook et al. (2008) explain that when resources are valuable, generating at least a temporary competitive advantage, it will generate a sustainable advantage when resources are difficult to imitate. Newbert (2008) explains further that the resources can lead a firm to attain competitive advantage, and then lead to better performance. Indeed, there are tangible and intangible resources that much recent research in RBT has focused on a firm's intangible resources to generate a sustained competitive advantage (Roxas\&Chadee, 2011). In addition, RBT is often employed as a theory of firm towards the literature for a better understanding of firm processes and strategic orientations (Meyskenset al. 2010; Foss, 2012).

\section{Proposed Model}

As stated in the introduction section, the main objective of this paper is to propose a model that illustrates the relationship between EO, MO, LO, ATF and SMEs performance. From the review of existing literature on EO, MO, LO, ATF and SMEs performance as discussed in the preceding sections, the proposed model is developed. Hence, Figure 1 indicates the moderating effect of ATF on the relationship between EO, MO, LO and SMEs performance. It implies that EO, MO, LO may have direct relationship with SMEs performance. It also implies that the relationship between EO, MO, LO and SMEs performance are contingent on ATF.

Figure 1: Proposed model

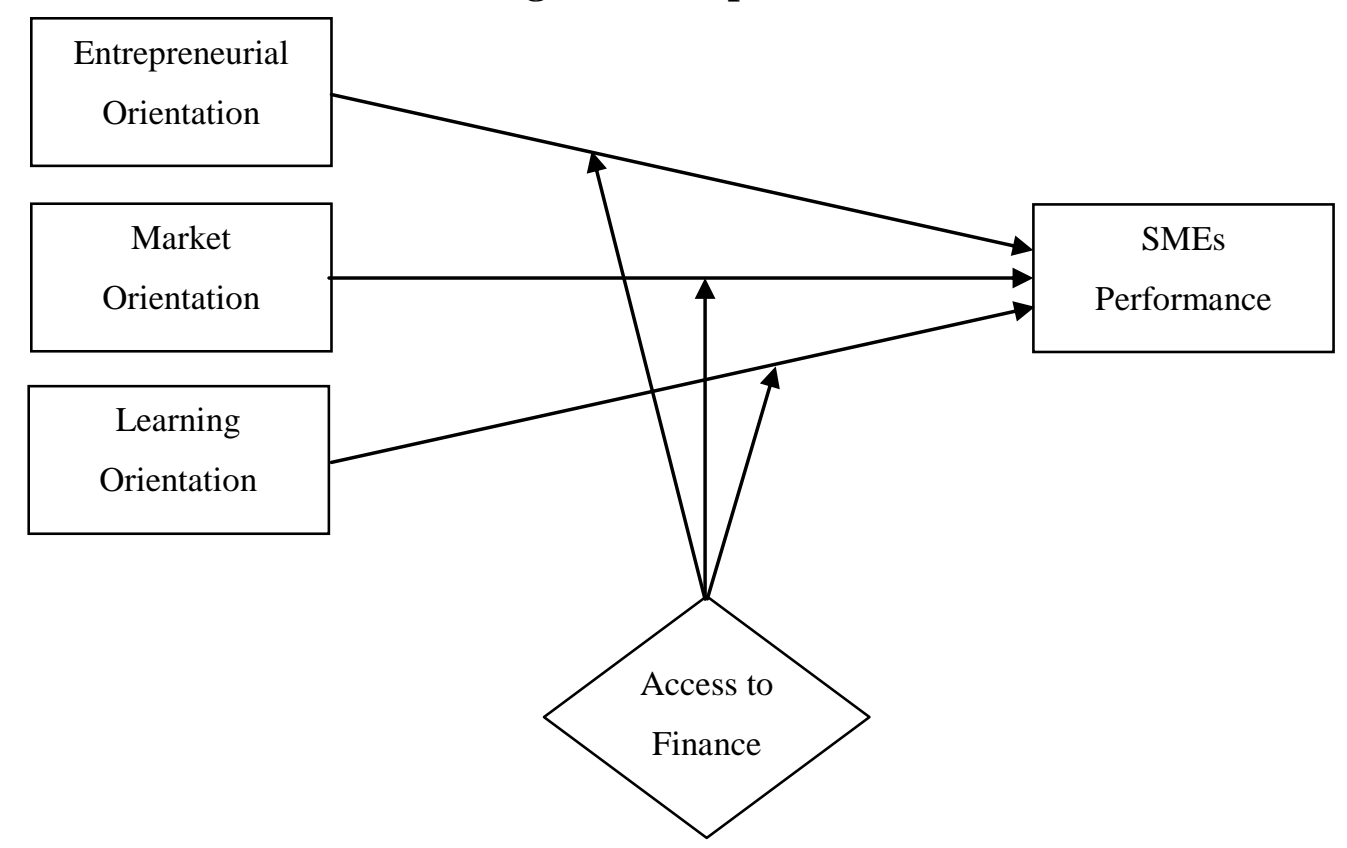

\section{Methodology}

This study follows the quantitative research design. According to Sekaran and Bougie (2013, p.95), research design is referred to "a blueprint for the collection, measurement, and analysis of data based on the research questions of interest". The key features of quantitative studies are the use of instruments such as surveys to collect data and reliance on theory to test statistical hypotheses (Harwell, 2011). This study adopts a survey research design by collecting primary data from the respondents due to the study involves 
collecting data directly from SME owner-managers in order to examine the moderating effect of ATF on the relationship between EO, MO, LO and SMEs performance. Hence, a survey method using questionnaire as the instrument for data collection is found to be more appropriate for this study.

\section{Conclusion}

This paper presents a proposed model which intends to examine the moderating effect of ATF on the relationship between EO, MO, LO and SMEs performance. The proposed model will provide several theoretical and practical contributions with regard to the performance of SMEs. Firstly, the findings will provide a clear understanding of the significant role of EO, MO, LO in improving SMEs performance according to Bosoet al. (2013) argue that the literature have not yet acknowledged, whether it is appropriate for a firm to increase its returns by investing in EO and MO. Secondly, the findings will help owner-manager of SMEs to understand the key factors that should be encouraged and avoided in order to improve their firm performance which then, in turn, will lead to increase levels of national GDP and employment rate consequently. Thirdly, the proposed model implies that ATF may moderate the relationship between EO, MO, LO and SMEs performance which can be interpreted further that the activities of EO, MO, LO may have a greater impact on SMEs performance when ATF is highly supportive. The future study should pay attention to SMEs from developing countries such as Thailand where the study on the issue is still limited that may provide a clear understanding of firm performance. In addition, Hussain et al. (2015) argue that paying attention on a single industry will provide a deeper understanding of the strategic orientation in order to improve business performance.

\section{References}

Adomako, S., \&Danso, A. (2014). Financial literacy and firm performance: The moderating role of financial capital availability and resource flexibility. International Journal of Management \& Organizational Studies, 3(4), 1-15.

Adomako, S., Danso, A., \&Damoah, J. O. (2016).The moderating influence of financial literacy on the relationship between access to finance and firm growth in Ghana.Venture Capital, 18(1), 4361.

Affendy, A. H., Asmat-Nizam, Abdul-Talib, \&Farid, F. S. (2015). Entrepreneurial orientation effects on market orientation and SMEs business performance: A SEM approach. Review of Integrative Business \& Economics Research, 4(3), 259-271.

Ahmad, S. Z., \&Arif, A. M. M. (2015).Strengthening access to finance for women-owned SMEs in developing countries.Equality, Diversity and Inclusion: An International Journal, 34(7), 634-639.

Ali, S., Rashid, H., \& Khan, M. A. (2014). The roll of small and medium enterprises and poverty in Pakistan: An empirical analysis. Theoretical and Applied Economics, 4(593), 67-80.

Aminu, I. M., \&Shariff, M. N. M. (2014).Mediating role of access to finance on the relationship between strategic orientation and SMEs performance in Nigeria: A proposed research framework.International Journal of Management Research \& Review, 4(11).1023-1035.

Anderson, B. S., \& Eshima, Y. (2013).The influence of firm age and intangible resources on the relationship between entrepreneurial orientation and firm growth among Japanese SMEs. Journal of Business Venturing, 28(3), 413- 429.

Apaydin, F. (2011).Moderating effect of adaptability on the relationship between two forms of market orientation and performance. Interdisciplinary Journal of Contemporary Research in Business, 3(2), 1364-1377.

Arora, R. U. (2014). Access to finance: An empirical analysis. European Journal of Development Research, 26(5), 798-814.

Arshad, R., Mansor, S. M., \& Othman, R. (2012).Market orientation, firm performance and the mediating effect of corporate social responsibility.The Journal of Applied Business Research, 28(5), 851-860.

Asare, A. O. (2014). Challenges affecting SME's growth in Ghana.OIDA International Journal of Sustainable Development, 7(6), 23-28. 
Awasthy, R., \& Gupta, R. K. (2011). Is learning orientation in manufacturing and service firms different in India? The Learning Organization, 18(5), 406-422.

Bae, K., Han, D., \&Sohn, H. (2012).Importance of access to finance in reducing income inequality and poverty level.International Review of Public Administration, 17(1), 55-77.

Barney, J. (1991). Firm resources and sustained competitive advantage. Journal of Management, 17(1), 99-120.

Barney, J. B., Ketchen Jr., D. J., \& Wright, M. (2011). The future of resource-based theory: Revitalization or decline? Journal of Management, 37(5), 1129-1315.

Baron, R. M., \& Kenny, D. A. (1986). The moderator-mediator variable distinction in social psychological research: Conceptual, strategy, and statistical considerations. Journal of Personality and Social Psychology, 51(6), 1173-1182.

Belanova, K. (2013). Access to finance of small and medium-sized enterprises in Slovakia.Economic Review, 42(3), 277-290.

Boso, N., Story, V. M., \&Cadogan, J. W. (2013). Entrepreneurial orientation, market orientation, network ties, and performance: Study of entrepreneurial firms in a developing economy. Journal of Business Venturing, 28(6), 708-727.

Brahma, S. S., \& Chakraborty, H. (2011). From industry to firm resources: Resource-based view of competitive advantage. The IUP Journal of Business Strategy, 8(2), 7-21.

Campos, H. M., de la Parra, J. P. N., \&Parellada, F. S. (2012). The entrepreneurial orientationdominant logic-performance relationship in new ventures: An exploratory quantitative study. BAR, Rio de Janeiro, 9(4), 60-77.

Chandrakumara, A., Zoysa, A. D., \&Manawaduge, A. (2011). Effects of the entrepreneurial and managerial orientations of owner-managers on company performance: An empirical test in Sri Lanka. International Journal of Management, 28(1), 139-199.

Charles, L., Joel, C., \&Samwel, C. (2012).Market orientation and firm performance in the manufacturing sector in Kenya.European Journal of Business and Management, 4(10), 2027.

Chauhan, S. (2014). Access to finance in Madhya Pradesh: An exploratory study. Indian Journal of Commerce \& Management Studies, 5(2), 8-17.

Cheng, W., Hailin, L., \&Hongming, X. (2008).The importance of social capital and learning orientation for leveraging knowledge capabilities in transition China. Paper presented at the Fourth International Conference on Wireless Communications, Networking and Mobile Computing, Dalian.

Covin, J. G., \&Slevin, D. P. (1989).Strategic management of small firms in hostile and benign environments.Strategic Management Journal, 10, 75-87.

Cowling, M., \& Liu, W. (2013). The effect of enterprises' growth orientation and access to finance on small firm performance in a global economic recession (summary).Frontiers of Entrepreneurship Research, 33(6).

Crook, T. R., Ketchen, D. J., Combs, J. G., \& Todd, S. Y. (2008). Strategic resources and performance: A meta-analysis. Strategic Management Journal, 29(11), 1141-1154.

Dada, O., \& Watson, A. (2013). Entrepreneurial orientation and the franchise system: Organizational antecedents and performance outcomes. European Journal of Marketing, 47(5/6), 790-812.

Eggers, F., Kraus, S., \& Hughes, M. (2013). Implications of customer and entrepreneurial orientations for SME growth.Management Decision, 51(3), 524-546.

Evans, O., Josephine, P., \&Yeboah, O. (2015). Challenges faced by SMEs in accessing credit in Tamale. Global Journal of Commerce \& Management Perspective, 4(5), 32-39.

Ferreira, J., Azevedo, S. G., \& Ortiz, R. F. (2011).Contribution of resource-based view and entrepreneurial orientation on small firm growth.Cuadernos de Gestion, 11(1), 95-116.

Foss, N. J. (2012).Entrepreneurship in the context of the resource-based view of the firm.In K. Mole, \& M. Ram (Eds.), Perspectives in entrepreneurship: A critical approach (pp.120-133). United Kingdom: Palgrave Macmillan.

Frank, H., Kessler, A., Mitterer, G., \&Weismeier-Sammer, D. (2012).Learning orientation of SMEs 
and its impact on firm performance.Journal of Marketing Development and Competitiveness, 6(3), 29-41.

Gaur. S. S., Vasudevan, S., \& Gaur, A. S. (2011). Market orientation and manufacturing performance of Indian SMEs: Moderating role of firm resources and environmental factors. European Journal of Marketing, 45(7/8), 1172-1193.

Gheysari, H., Rasli, A., Roghanian, P., \&Norhalim, N. (2012).A review on the market orientation evolution.Procedia-Social and Behavioral Sciences, 40, 542-549.

Gunto, M., \& Alias, M. H. (2014).The impact of networking on the SMEs' ability to access financial government support in Malaysia.South East Asia Journal of Contemporary Business, Economics and Law, 5(3), 9-17.

Hart, S. L., \& Dowell, G. (2011). A natural-resource-based view of the firm: fifteen years after. Journal of Management, 37(5), 1464-1479.

Harwell, M. (2011).Research design in qualitative/quantitative/mixed methods.In C. Conrad, \& R. Serlin (Eds.), The SAGE handbook for research in education: Pursuing ideas as the keystone of exemplary inquiry (pp. 147-165). Thousand Oaks, CA: SAGE Publications, Inc.

Herath, H. M. A., \& Mahmood, R. (2013). Strategic orientation based research model of SME performance for developing countries. Review of Integrative Business \& Economics Research, 2(1), 430-440.

Herath, H. M. A., \& Mahmood, R. (2014). Strategic orientations and SME performance: Moderating effect of absorptive capacity of the firm. Asian Social Science, 10(13), 95-107.

Hussain, J., Ismail, K., \& Shah, F. A. (2015). The effect of market and entrepreneurial orientations on organizational performance: Study of Malaysian SMEs. City University Research Journal, 5(2), 203-218.

Jaworski, B. J., \&Kohli, A. K. (1993). Market orientation: Antecedents and consequences. Journal of Marketing, 57, 53-70.

Kamunge, M. S., Njeru, A., \&Tirimba, O. I. (2014). Factors affecting the performance of small and micro enterprises in Limuru town market of Kiambu County, Kenya. International Journal of Scientific and Research Publications, 4(12), 1-20.

Kantur, D. (2016). Strategic entrepreneurship: mediating the entrepreneurial orientation- performance link. Management Decision, 54(1), 24-43.

Katua, N. T. (2014). The role of SMEs in employment creation and economic growth in selected countries.International Journal of Education and Research, 2(12), 461-471.

Khalique, M., Md. Isa, A. H., Shaari, J. A. N., \&Ageel, A. (2011). Challenges faced by the Small and Medium Enterprises (SMEs) in Malaysia: An intellectual capital perspective. International Journal of Current Research, 3(6), 398-401.

Kira, A. R., \& He, Z. (2012). The impact of firm characteristics in access of financing by small and medium-sized enterprises in Tanzania. InternationalJournal of Business and Management, 7(24), 108-119.

Kohli, A. K., \&Jaworski, B. J. (1990). Market orientation: The construct, research propositions, and managerial implications. Journal of Marketing, 54, 1-18.

Lee, Y., Kim, S., Seo, M., \&Hight, S. K. (2015). Market orientation and business performance: Evidence from franchising industry. International Journal of Hospitality Management, 44, 28-37.

Li, Y. H., Huang, J. W., \& Tsai, M. T. (2009). Entrepreneurial orientation and firm performance: The role of knowledge creation process. Industrial Marketing Management, 38(4), 440-449.

Liu, W., Cowling, M., \& Zhang, N. (2014). The effect of enterprises' growth orientation and access to finance on small firm performance: UK evidence in an economic recession. IBSS Working Papers, 3, 3-25.

Long, H. C. (2013). The relationship among learning orientation, market orientation, entrepreneurial orientation, and firm performance of Vietnam marketing communications firms.Philippine Management Review, 20, 37-46.

Lucas, M. T., \&Kirillova, O. M. (2011).Reconciling the resource-based and competitive positioning 
perspectives on manufacturing flexibility.Journal of Manufacturing Technology Management, 22(2), 189-203.

Lumpkin, G. T., \&Dess, G. G. (1996). Clarifying the entrepreneurial orientation construct and linking it to performance. The Academy of Management Review, 21(1), 135-172.

Ma, W., Zhu, G., \&Hou, Y. (2011).Learning orientation, process innovation, and firm performance in manufacturing industry.Advances in Information Sciences and Service Sciences, 3(11), 357-364.

Mahmood, R., \& Hanafi, N. (2013). Learning orientation and business performance of women- owned SMEs in Malaysia: The mediating effect of competitive advantage. British Journal of Arts and Social Sciences, 11(2), 150-161.

Mahmoud, M. A. (2011). Market orientation and business performance among SMEs in Ghana. International Business Research, 4(1), 241-251.

Mahmoud, M. A., \&Yusif, B. (2012).Market orientation, learning orientation, and the performance of nonprofit organizations (NPOs).International Journal of Productivity and Performance Management, 61(6), 624-652.

Martinette, L. A., \&Obenchain-Leeson, A. (2012). The relationship between learning orientation and business performance and the moderating effect of competitive advantage: A service organization perspective. Journal of Service Science, 5(1), 43-58.

Martinette, L., Obenchain-Leeson, A., \& Gomez, G. (2014). Relationship between learning orientation and business performance and the moderating effect of competitive advantage: An accounting services firm's perspective. International Business \& Economics Research Journal, 13(4), 779-792.

Ma'atoofi, A. R., Ahmadian, A. A., Vezvari, A. R., Khanghah, A. R., Kykanloo, R. J., \&Shirzadi, F. (2012). Market orientation versus entrepreneurship: The necessity to adopt a strategic equilibrant approach to create innovation in product. Trends in Advanced Science \& Engineering, 3(2), 39-42.

Ma'atoofi, A. R., \&Tajeddini, K. (2010). The effect of entrepreneurship orientation on learning orientation and innovation: A study of small-sized business firms in Iran. International Journal of Trade, Economics and Finance, 1(3), 254-260.

Meyskens, M., Robb-Post, C., Stamp, J. A., Carsrud, A. L., \& Reynolds, P. D. (2010). Social ventures from a resource-based perspective: An exploratory study assessing global Ashoka fellows. Entrepreneurship Theory and Practice, 34(4), 661-680.

Miller, D. (1983). The correlates of entrepreneurship in three types of firms.Management Science, 29(7), 770-791.

Moreira, D. F. (2016). The micro economic impact on growth of SMEs when the access to finance widens: Evidence from internet \& high-tech industry. Procedia-Social and Behavioral Sciences, 220, 278-287.

Musamali, M. M., \&Tarus, D. K. (2013). Does firm profile influence financial access among small and medium enterprises in Kenya? Asian Economic and Financial Review, 3(6), 714-723.

Narver, J. C., \& Slater, S. F. (1990).The effect of a market orientation on business profitability. Journal of Marketing, 54(4), 20-35.

Newbert, S. L. (2008). Value, rareness, competitive advantage, and performance: A conceptual- level empirical investigation of the resource-based view of the firm. Strategic Management Journal, 29(7), 745-768.

Ngek, N. B. (2014). Determining high quality SMEs that significantly contribute to SME growth: Regional evidence from South Africa.Problems and Perspectives in Management, 12(4), 253-264.

Niculescu, M., Xu, B., Hampton, G. M., \& Peterson, R. T. (2013).Market orientation and its measurement in universities.Administrative Issues Journal: Education, Practice, and Research, 3(2).

Nybakk, E. (2012). Learning orientation, innovativeness and financial performance in traditional manufacturing firms: A higher-order structural equation model. International Journal of Innovation Management, 16(5), 1-28.

O’Shannassy, T. (2008). Sustainable competitive advantage or temporary competitive advantage: 
Improving understanding of an important strategy construct. Journal of Strategy and Management, $1(2), 168-180$.

Oreoluwa, A. R. (2011). Small and medium scale enterprises and economic growth in Nigeria: An assessment of financing options. Pakistan Journal of Business and Economic Review, 2(1), 78-97.

Qu, R., \& Zhang, Z. (2015).Market orientation and business performance in MNC foreign subsidiaries-Moderating effects of integration and responsiveness.Journal of Business Research, 68(5), 919-924.

Ramayah, T., Samat, N., \& Lo, M. (2011).Market orientation, service quality and organizational performance in service organizations in Malaysia.Asia-Pacific Journal of Business Administration, 3(1), 8-27.

Rauch, A., Wiklund, J., Lumpkin, G. T., \&Frese, M. (2009). Entrepreneurial orientation and business performance: An assessment of past research and suggestions for the future. Entrepreneurship Theory and Practice, 33(3), 761-787.

Razak, R. A. (2011). Entrepreneurial orientation as a universal remedy for the receding productivity in Malaysian small and medium enterprises: A theoretical perspective. International Journal of Business and Social Science, 2(19), 249-257.

Richard, E. M., \& Mori, N. G. (2012). SMEs access to financial services: Bankers' eye. Chinese Business Review, 11(2), 217-223.

Roach, D. C. (2011).The impact of product management on SME firm performance.Journal of Research in Marketing and Entrepreneurship, 13(1), 85-104.

Rossi, M. (2014). SMEs' access to finance: An overview from Southern Italy. European Journal of Business and Social Sciences, 2(11), 155-164.

Roxas, H. B., \&Chadee, D. (2011).A resource-based view of small export firms' social capital in a Southeast Asian country.Asian Academy of Management Journal, 16(2), 1-28.

Saqib, S., \& Rashid, S. (2013). Resource based view of the firm: The nature of resources required for competitive advantage. International Journal of Management and Organizational Studies, 2(1), 92-95.

Sekaran, U., \&Bougie, R. (2013).Research methods for business: A skill-building approach (6th ed.).

United Kingdom: John Wiley \& Sons Ltd.

Silivestru, D. R. (2012). European SMEs and economic growth: A firm size class analysis. Analele Stiintifice Ale Universitatii “Al.I. Cuza” Din Iasi.StiinteEconomice/Scientific Annals of the "Al. I. Cuza”, 59(2), 143-151.

Sinkula, J. M., Baker, W. E., \&Noordewier, T. (1997). A framework for market- based organizational learning: Linking values, Knowledge, and Behavior. Academy of Marketing Science, 25(4), 305-318.

Suliyanto, S., \& Rahab, R. (2012). The role of marketing orientation and learning orientation in improving innovativeness and performance of small and medium enterprises. Asian Social Science, 8(1), 134-145.

Tajeddini, K. (2009). The impact of learning orientation on NSD and hotel performance: Evidence from the hotel industry in Iran. Education, Business and Society: Contemporary Middle Eastern Issues, 2(4), 262-275.

Tan, C. S. L., \&Smyrnios, K. X. (2014). What drives learning orientation in fast growth SMEs? International Journal of Entrepreneurial Behaviour\& Research, 20(4), 324-350.

Tope, S. A., \&Rosli, M. (2014). Integration of entrepreneurial orientation and dynamic capabilities in dynamic environment of small and medium enterprises: A case of Nigerian export firms. International Journal of Economics, Commerce and Management, 2(10), 1-11.

Wolff, J. A., Pett, T. L., \& Ring, J. K. (2015). Small firm growth as a function of both learning orientation and entrepreneurial orientation: An empirical analysis. International Journal of Entrepreneurial Behavior \& Research, 21(5), 709-730.

Wong, S. K. S. (2012). The influences of entrepreneurial orientation on product advantage and new 
product success.Journal of Chinese Entrepreneurship, 4(3), 243-262.

Zarook, T., Rahman, M. M., \&Khanam, R. (2013). Does the financial performance matter in accessing to finance for Libya's SMEs? International Journal of Economics and Finance, 5(6), 11-19.

Zhang, Y., \& Zhang, X. (2012). The effect of entrepreneurial orientation on business performance: A role of network capabilities in China. Journal of Chinese Entrepreneurship, 4(2), 132-142. 